\title{
METHODS FOR THE STUDY OF SCLEROTIAL DORMANCY IN SCLEROTIUM CEPIVORUM UNDER NEW ZEALAND CONDITIONS
}

\author{
G.E. HARPER and A. STEWART
}

\author{
Soil, Plant and Ecological Sciences, PO Box 84, Lincoln University, Canterbury
}

Sclerotium cepivorum is the casual agent of onion white rot. Dormancy is the term used here to describe why sclerotia sometimes do not germinate in response to onion root exudates, e.g. diallyl disuphide (DADS). Overseas studies suggest that dormancy lasts 1-3 months. We tested for dormancy using three isolates of S. cepivorum in two soil types. We compared two methods. The first one involved removing sclerotia, after conditioning, into Petri dishes before application of DADS. The second involved applying DADS to sclerotia buried in bags in the field. We found that dormancy lasted a minimum of 8 weeks and occurred in all isolates tested. Soil type had minimal influence on the breaking of dormancy. The method involving Petri dishes was prone to problems caused by contaminating fungi, which grew over the sclerotia and made the scoring of germination difficult. The alternative method was more effective and more closely imitated field conditions. This work continues using a greater number of isolates and supports ongoing studies on the use of DADS for disease control.

\section{SEASONAL GRAZING BY CANADA GEESE (BRANTA CANADENSIS) ON SOUTH ISLAND HIGH-COUNTRY PASTURE}

\author{
A.D. WIN and G.J. HICKLING \\ Ecology \& Entomology Group, PO Box 84, Lincoln University, Canterbury, New Zealand
}

There is ongoing debate between landowners and recreational hunters as to the significance of grazing by Canada geese (Branta canadensis) on high-country farmland. The Canada Goose Management Plan (1995), which includes in its aims the alleviation of such impacts, was developed in the absence of quantitative measures of grazing intensity. Consequently, we have been making monthly observations of the geese present on 69 ha of paddocks adjacent to Lake Grassmere in inland Canterbury. During daylight hours, when their main activity was grazing, mean goose density in 1999 ranged from 3.7 geese/ha in spring to 20.2 geese/ha in autumn. The geese were most aggregated in winter, when densities on the preferred paddocks exceeded 40 geese/ha. Based on published data on feed intake, we estimate that the forage intake of the goose population on the 69 ha study area ranged from $90 \mathrm{~kg}$ per day in spring to $490 \mathrm{~kg} /$ day in autumn. These estimates, which will be validated by exclosure studies that are now in progress, will assist managers to better assess the costs versus benefits of any future goose management in the high country. 